\section{Typhoon disaster politics in pre- 1945 Asia: three case studies}

\author{
Gerry van Klinken \\ Department of Anthropology, University of Amsterdam, \\ Amsterdam, Netherlands and \\ KITLV, Leiden, Netherlands
}

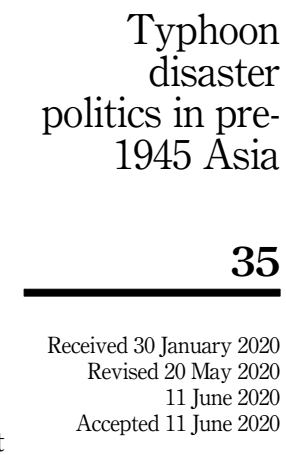

\begin{abstract}
Purpose - This paper focuses on the adaptations societies make to climate-related disasters. How they learnt from them in the past should indicate how they will respond in the more climate-stressed future. National typhoon disaster politics arise when citizens demand disaster protection from their state.

Design/methodology/approach - The paper analyzes one episode of typhoon politics in each of three Asian countries before 1945: the Philippines (1928), India (1942) and Japan (1934). These three countries show high variance in state capacity and level of democracy. Discourse data are found in contemporary newspaper accounts.

Findings - In each case, the typhoon disaster politics were shaped by the "distance" (geographical, institutional, class and cultural) between citizen-victims and the state. Where that distance was great (rural Philippines, Bengal-India), the state tended to minimise victimhood. Where it was small (urban Japan), adaptation was serious and rapid.

Social implications - The findings should stimulate public discussion of the way in which past social relations and power dynamics surrounding climate-related disasters might influence the present. As the political character of climate change adaptation grows clearer, so does the need for debate to be well-informed. Originality/value - Most historical work on climate-related disasters has focused either on the natural phenomena, or on their societal impact. The present paper's focus on adaptation is part of a small but growing scholarly effort to bend the debate towards the evolution of adaptive capacity.
\end{abstract}

Keywords Disasters, Typhoons, Cyclones, Philippines, Bengal, Japan, Politics, Rural, Urban, Class,

Democracy, Adaptation

Paper type Research paper

\section{Introduction}

Of the 1.2 million killed by storms worldwide in the twentieth century, 1.1 million died in Asia [1]. 190 Per cent of those died due to storm surges that momentarily cause sea-level to rise by up to $5 \mathrm{~m}$ or even more, inundating low-lying coastal areas. Climate change is expected to increase the proportion of severe tropical storms, and their impact on human society will grow due to rising sea-levels (Knutson et al., 2020). How will societies cope with them? Studies on how they coped in the past might help answer that question. This paper looks comparatively at the politics around a typhoon disaster in each of three Asian countries. The case studies are expected to throw light on longer-term dynamics in those societies.

(C) Gerry van Klinken. Published by Emerald Publishing Limited. This article is published under the Creative Commons Attribution (CC BY 4.0) licence. Anyone may reproduce, distribute, translate and create derivative works of this article (for both commercial \& non-commercial purposes), subject to full attribution to the original publication and authors. The full terms of this licence may be seen at http:// creativecommons.org/licences/by/4.0/legalcode.

Thanks to participants in meetings where versions of this paper were presented: Ateneo de Manila University, Manila, 29 January 2018; KITLV, Leiden, 7 March 2019; Gadjah Mada University, Yogyakarta, 29 August 2019. Travel funding was provided by KITLV and the ARC Linkage Project "Hazards, tipping points, adaptation and collapse in the Indo-Pacific world, post-1000 C.E." Thanks also to Fiona Williamson for her encouragement, and to two anonymous reviewers at this journal for helpful criticism.

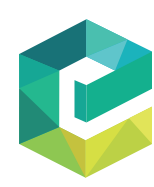

Disaster Prevention and Management: An International Vol. 30 No. 1,2021 pp. $35-46$ Emerald Publishing Limited
0965-3562 
DPM

30,1

Studies of (series of) past climate-related disasters belong to historical climatology. (The history of meteorology increasingly converges with this field, Vogel, 2009). It has grown into a large field since its origins in the 1960s. Most work has focused on climatological reconstructions - first by historians uncovering new archives, then by physical scientists using tree-rings, isotopes and other sources. A lot, too, has been done on the impact of climatic events and climate change on human societies, including the impact of storm disasters. Most of this research has concerned periods before 1900. Social scientists from a diversity of disciplines have been calling for historical research on the adaptations that societies have made to these events, particularly in the twentieth century (Carey, 2012). Some notable studies along these lines have appeared in recent years - for example on tropical storms in the Caribbean (Church, 2017; Johnson, 2011; Perez, 2001; Rohland, 2019), in the Philippines (Bankoff, 2003; Warren, 2018) and the head of the Bay of Bengal (Kingsbury, 2019).

They illustrate the crucial role of citizenship and of social movements in increasing a society's adaptive capacity. Yet, so far, the weight of scholarship in this area has been insufficient to move the public debate. Instead of being about how past social relations and power dynamics surrounding climate issues might influence the present, public discourse has been about policy recommendations to mitigate future warming and about the clash between climate change believers and sceptics (Carey, 2012). The present article aims to take up Carey's call for a stronger emphasis on social history and cultural analysis.

How might we approach a study of the power dynamics surrounding historical typhoon disasters? I briefly present three analytical concepts for reconstructing historical case studies. The first concerns space. A typhoon (in India called a cyclone) has an impact zone whose dimensions normally differ from those of the most relevant political zone. It wreaks its severest damage in an area defined by its diameter, typically around $160 \mathrm{~km}$. The coastal zone where it makes landfall is often fertile and densely populated. A storm surge can kill when sea-water overtops coastal defences and floods low-lying lands. High-speed winds may destroy infrastructure and crops. Heavy rain may cause riverine flooding and landslides.

Survivors in the impact zone demand help: relief, compensation and insurance against future disasters. They speak to their local community, to local or national governments or to the international community. In the twentieth century, it is the nation-state that offers the greatest potential for effective assistance in the case of large disasters. The IPCC (2007, chap. 17) has called for more research on the capacity to adapt to climate change, particularly in developing regions and particularly with a view to "identifying areas for leverage and action by government." The typhoon disaster politics considered here therefore connect the local communities affected by disaster to national politics. The spatial gap separating survivors claiming rights to assistance from those best able to realise those rights creates action-at-a-distance problems. Tracking communication processes across that gap is a key to understanding eventual outcomes.

The second analytical concept concerns politics. A disaster often creates contentious power dynamics. "The moment that rights are claimed or denied can be seen as potential tipping points for political change", writes an agenda-setting paper on what its authors called "disaster politics" (Pelling and Dill, 2010, p. 34). The most famous example of typhoon-induced political change was the Bangladesh war of independence, triggered by dissatisfaction among survivors of the Bhola cyclone disaster in November 1970. Many other typhoon disasters claiming thousands of dead and billions in damage have produced politics that call for our examination. Only by studying the history of actual weather-related disaster politics will we know how social relations are likely to develop as climate change begins to bite. Will we discover in this history of citizen action an alternative mode of governance over weather-related disasters? One in which people, democracy and equality matter? 
The third analytical concept connects space with politics. The political geographer Diane Davis (1999) introduced the useful idea of "citizens' distance from the state". She understands space phenomenologically, as both a material and a social construct. It is a relational notion that straddles state and societal domains simultaneously. Citizens' distance from the statemeaning both elite society and government bureaucracies can be analysed in terms of four dimensions. The first is geographical-how close are people physically to key centres of power? The second is institutional-how accessible are key institutions to them? The third is class-how much influence do they have within the most powerful classes? The fourth is cultural-how well can they communicate within the dominant culture? Citizens whose distance to the state is small along all four dimensions tend to use formal institutions to claim their rights. Those far away are so alienated they may resort to revolution, or perhaps to resignation. Those somewhere in the middle are likely to engage in social movements.

We now proceed to the case studies. This paper approaches typhoon disaster politics in Asia historically and comparatively. It is part of a larger research project investigating the evolution of actual typhoon coping capacities within several twentieth-century Asian societies. The project extends historical work by others aiming to explain why the modern state-a universal phenomenon in the past century - has such uneven capacities to cope with climate-related disasters. A recent statistical paper suggests, plausibly, that (1) wealth and (2) democracy are good indicators of how well a state can handle disaster (Lin, 2015). Most states in the world are not wealthy, high-capacity democracies. To understand these real-world situations, we need to open the black box of statistical correlation and expose the political processes that might explain the correlation.

The case studies come from three countries in Asia whose histories span a range of political economies. In each I have chosen a major disaster that falls in roughly the same period, namely the long 1930s (1928-1942), thus keeping global conditions constant. Japan was then the richest country in Asia, with a GDP per capita of about USD2,000 in constant 2000 dollars (Coppedge et al., 2018). The Philippines was next at USD1,400 and India the poorest at USD680. Democratic consultation was hampered by colonialism and militarism. On a "Core Civil Society Index" from 0 to 1 , the V-DEM project rated the Philippines as the best at 0.55 at this time, Japan at 0.4 (and rapidly declining) and India at a miserable 0.3. Japan was an industrialising economy. Its democratic institutions were under persistent attack by right-wing militarists. The Philippines and India were agrarian economies. Both were colonial and struggling with rising nationalist movements, but the Philippines had made more progress than India.

The present, preliminary, study mainly uses English-language newspaper accounts archived online to reconstruct the course of disaster politics surrounding each event. For Japan, I consulted the Japan Times (JT) (August 1932-March 1935) and for India, the Times of India (TI) (March 1942-November 1943). For the Philippines, the only online archive to which I had access was the New York Times (NYT) (which I searched 1885-1995) [2].

\section{The Philippines, 1928}

Typhoons in the Philippines are common and essential to agriculture. In 1928 northern Luzon experienced a tropical storm crossing over or near its coast in each of April, June, July and three in August. None were particularly fierce. But on 23 November a typhoon that today would be classified as Category 3 on the Saffir-Simpson scale passed across the east coast of Samar (Ribera et al., 2005) [3]. Scientists in Manila had pioneered typhoon meteorology since the 1870s (Anduaga, 2019). They had tracked this one via ship reports for three days. Warnings had been wired to the provinces, evidently without significant effect. The typhoon then moved slowly, swinging towards the north and passing over Samar, Leyte and southern Luzon. After passing out to sea, it bent back towards the east and hit northern Luzon in a weakened state. Strong winds, floods and storm surges killed over 500. More than 25,000 homes were wholly or partially destroyed and half a million pesos damage done to public 
DPM

30,1

works alone (USD250,000 in 1928, equivalent to almost USD4mn in 2019). Governor General Colonel Henry Stimson wrote in his annual report (Governor General of the Philippine Islands, 1930): "[F]rom the width of its path and its unusual duration, rather than from exceptional violence, [this typhoon] exceeded in destructiveness almost all of the typhoons which have visited the islands since the American occupation." Its toll was the worst in the Philippines since 1,000 had been killed by an immense $7 \mathrm{~m}$ storm surge in Cebu in 1912 and 6,400 by a storm surge at Tacloban in 1897 (Needham et al., 2015).

There were disaster politics around this typhoon, but only the elite end of them is visible in the New York Times. The victims' "distance to the state" was so great, on every one of Davis' four dimensions, that they never appear in the story on their own terms. Instead, we see mainly an energetic Governor General - newly appointed and anxious to do a better job than his predecessor. Although the typhoon's edge passed over the capital Manila, it had done its worst damage in Samar, $500 \mathrm{~km}$ to the southeast. Information reached Manila through the executive branch of government. Stimson immediately set about distributing relief to the disaster areas. A naval flotilla fortuitously present in the Manila harbour helped him circumvent broken lines of communication and the normal difficulties with transport. By 1928, the expectation had become routine that the American-appointed Governor General would undertake some kind of relief work after a major disaster. In 1897 Americans were not yet in the archipelago, and even in 1912, newspaper readers in the US did not learn of any official relief effort. But the Governor General had sent a relief expedition in October 1915 after a typhoon of "extraordinary violence" had destroyed most of the coastal town of Tabaco in southern Luzon, killing 100. This one was much bigger. It was the first major calamity to strike the archipelago under American administration.

After personally visiting the disaster zone, Stimson became convinced it demanded a developmental as well as a humanitarian mission. People in Samar were "habitually upon a very low standard of living. .. habitually undernourished," he wrote. The reason was that "frequently recurring typhoons" ensured they "have never been able to pull themselves out of a very low standard of physical welfare." Once they had used up the broken coconut and hemp trees, he feared they would face real famine, "several months after the surrounding world has forgotten all about the storm itself." He therefore wanted to distribute seeds of quick-growing crops, encourage crop diversification, employ locals on roadbuilding and start sanitation projects. To pay for it all, he successfully urged the Philippine Congress to convene a special session that set aside a million pesos in relief aid. This corresponded to USD0.5 million or almost USD8 million in 2019 dollars. He asked the Red Cross in America to raise a matching subsidy.

Stimson's development project reflected the idealism of US President William McKinley, who had promised the Filipino people a policy of "benevolent assimilation, substituting the mild sway of justice and right for arbitrary rule [, for] the greatest good of the governed." The politics lay in squaring that thought with American imperial economics and security concerns. Economics were central to the prominent reporting of the disaster in America. The Philippines were persistently portrayed as a poor, underdeveloped, typhoon-swept colony with natives who were fatalistic when not rebellious. Doubts had long been raised whether their agrarian export potential - sugar, copra and hemp - could be brought up to compete with the typhoon-free and well-run Netherlands Indies to the south. Soon after an estimate of the number of dead had been made (no more accurate count than "over 500" was ever established), foreign editors moved on to ask what impact the typhoon might have on the export crop. None considered the idea compelling that Philippine profits ought primarily to benefit Filipino citizens. Bankoff (2003, p. 87) has calculated that historically in the Philippines, "assistance in general remains inadequate, comprising only a small fraction of the actual losses incurred through natural hazards."

Security remained a concern in 1928. American military operations had left a bad taste in the mouths of Filipino nationalists. Typhoons were seen in American military circles as one of 
the potential sources of insecurity. Stimson's relief effort therefore also had a political purpose, namely to win Filipino hearts and minds for the Americans.

Hearing local citizenship claims was part of Stimson's mission. It is surprising therefore that no Filipino politician appeared to speak out on behalf of the victims of the biggest disaster to strike the country in decades. One reason lies, ironically, in preceding American state-building efforts. These had obstructed the rise of a capable national democracy in the Philippines, and Filipino politicians had gone along with it. Republican US policymakers had resisted progressive attempts to strengthen central state agencies and to tame party "machines" in the Philippines (Abinales and Amoroso, 2005, pp. 134-135). Instead they had favoured the distribution of representative powers to more local subdivisions, starting with municipal areas. Yet the Filipino politicians who rose up through this system owed no allegiance to their local landless poor. The impoverished typhoon victims in Samar and Leyte did not have the vote until 1935. The emerging ruling class of legislators in Manila lived far from their constituencies, enjoying the spoils of office with their cronies. Even after independence in 1946, "those who sought to use the presidency to govern would have to work through elaborate patronage networks of politicians whose main concern was strengthening their own power, not assisting in the construction of an effective national authority" (Abinales and Amoroso, 2005, p. 170).

In conclusion, typhoon victims in the Philippines in 1928 were too distant from the central state on all four dimensions to make them heard directly to a broader national public. Geographically, they resided 500km from Manila. Institutionally, they were excluded from formal representative politics, and in class terms they were too poor to be heard by those in power except in a limited humanitarian way. Electoral dynamics disfavoured nationalist solidarity from below. Representative nationalist forces showed no interest in the rights of citizens to be protected from the effects of disasters. Instead, the victims were accorded a thin kind of developmentalist citizenship by an American-led administration concerned to build performance legitimation. Besides a small amount of aid disbursed by the central state, victims were dependent on the resources of their own local community, as they have continued to do (Bankoff, 2007). While improved forecasting gradually made warnings timelier and more accurate, little more "purposeful adjustment" (Burton et al., 1993) was made at a national level to reduce losses or share them should disaster strike again in future.

\section{Bengal, 1942}

The densely populated, deltaic head of the Bay of Bengal is one of the most cyclonevulnerable areas in the world. Disasters have periodically produced apocalyptic death tolls for centuries. Prior to 1942, twentieth-century cyclones with death tolls over 10,000 had occurred here in 1911 (120,000 dead) and 1919 (40,000). The storm that crossed the coast near the town of Contai on the morning of 16 October 1942 had been tracked for three days but was not particularly strong - a tropical storm on the Saffir-Simpson scale, perhaps a Category 1 (India Meteorological Department (IMD), 2018). A very late warning telegraphed to local government that morning failed to reach police stations. However, bathymetry and wind direction combined to create a storm surge $3-5 \mathrm{~m}$ high. It washed over a strip $11 \mathrm{~km}$ wide along the coast of Midnapore and 24-Parnagas districts. The surge travelled over 50km up the Hooghly and Rupnarayan rivers (as well as a couple of smaller rivers) into northern Midnapore, inundating the banks to $5 \mathrm{~km}$ on either side. Heavy rain meanwhile caused the rivers to swell coming down from the north. Nearly $1,200 \mathrm{~km}^{2}$ of low-lying delta land were swept by the storm surge. With nowhere to run, 11,000 drowned there. Another $1,000 \mathrm{~km}^{2}$ were swept by river flooding. The same storm surge also swamped the delta of the Mahanadi River in Odisha (then called Orissa), another agricultural area $200 \mathrm{~km}$ to the southwest, where it killed another 4,000. Altogether 188,000 cattle died (Greenough, 1982, upon whom most of

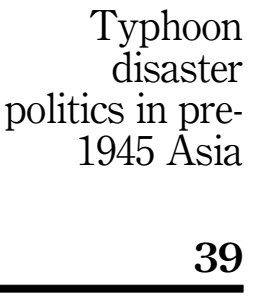

\section{9}


DPM

30,1

this account relies). About 7,400 villages were partly or wholly destroyed by the storm. Flood waters remained standing for weeks in many of them. Cholera, dysentery and other waterborne diseases thrived. The main rice crop of the season in this fertile agricultural region, known as aman, was badly damaged, as was a good portion of food stocks cultivators held at home. An unprecedented outbreak of fungal brown spot disease exacerbated the rice shortage.

The war effort developing in the same region turned the cyclone disaster into a governance disaster. Typhoon databases continue to quote a total death toll of between 40,000 and 61,000 , but the death toll due to the cascading typhoon and famine is 3.5-3.8 million. The first signs of distress had actually appeared before the cyclone. The first famine deaths occurred in May 1943. By August 1943, fully ten months after the cyclone and just as officials thought they had the problem under control, famine spiralled out of control. It was the last India was to experience.

How can this massive failure of governance be explained? Why did the Indian government simply "abandon" the victims of this disaster (Greenough, 1982, p. 264)? The answer can be sought in the four dimensions of distance that separated them from the state.

Geographically, the stricken area lay about 1,400 km from the colonial capital at Delhi. True, not all power resided there. The Bengali capital Calcutta was only a hundred kilometres removed from the cyclone footprint. But an absence of roads and bridges made the area difficult to access even from there. As it happened, the focus of national politics did move much closer to the delta in 1942. In April, Japan invaded Burma just across the water. But the population of the delta was then seen by those in charge of the war effort as too close for comfort. Rather than citizens with rights to protection, they were a nuisance to the rapidly developing national security crisis.

British military authorities expected the Japanese to launch an invasion into India within weeks. They instituted a draconian denial policy. To prevent the enemy from making use of small boats held by the local population, the military placed 66,500 of them in compulsory storage areas, failing to distribute food rations to make up for the interruption of supplies. They removed food stocks from the area. Food price rises, and the redirection of food from the starving rural districts to the workers in urban industries around Greater Calcutta considered essential to the war effort, were already causing signs of distress in July 1942. The military furthermore displaced 30-36,000 households to build forward bases that accommodated thousands of troops and associated labour looking towards the Burmese front. The newcomers added to the strain on food supplies. The money they brought with them caused massive local inflation, which impoverished the locals.

Culturally, too, the victims remained largely invisible to the mainstream of Indian society. When the disaster struck, the military demanded that news of it not be broadcast, lest the enemy learn that the storm had also destroyed military infrastructure. The first newspaper reports sketching the scale of the disaster appeared on 4 November, a full 18 days after landfall. The fact that thousands had drowned in Odisha as well did not reach the national newspapers until June 1943. The first real humans that newspaper readers saw were in descriptions - in defiance of the censors - of hungry refugees running along Calcutta's streets to escape city officials in August 1943, and subsequently of their corpses littering those same streets. Throughout the worst of the famine, government spokespersons played down the "exaggeration" of widespread death.

Class had robbed the victims of influence long before the disaster. The region was the poorest in India. Debt bondage and landlessness meant that, in a 1930 survey, the Bengali diet was the least nutritious in the world, always just short of famine (Greenough, 1982, p. 84). They were dependent on the patronage of local landowners to help them out in times of crisis. When these patrons themselves ran out of resources, they simply abandoned their peasants to their fate. 
Their poverty also excluded the victims from formal state institutions, despite recent moves towards democracy. The first Indian provincial elections just five years earlier gave the vote to millions but not to those with little or no land. When it came to relief, even local officials never felt enough urgency to invoke the Famine Act, which would have obliged them to increase funding. Private relief did come, but most of it was directed at urban middle class workers considered "priority classes" for their value to the war effort, rather than at the rural victims in the delta.

Burma had been India's main source of imported rice. When that source was suddenly cut off in the summer of 1942, civilian authorities grew anxious about maintaining all-India food security. They pushed up the export of rice from Bengal to the rest of India. When the perceived local rice shortage caused prices to rise - even before the disaster - government imposed maximum price controls in order to protect urban consumers. This worsened inequalities, yet failed to control black market profiteering [4]. Meanwhile, provincial administrators, attempting to feed their own populations and thus forestall unrest before feeding those next door, put up barriers to interprovincial trade. This policy immeasurably exacerbated the failures caused by the market and actually created famine. Cyclone refugees were unable to purchase food. Over a hundred thousand turned up on the streets of Calcutta, where they were hounded down by city council officials who wished to move them to shelters on the outskirts of the city.

The famine finally ended when, first, the Indian Army decisively brought in extra food, persuading Britain to deploy scarce wartime transportation for the purpose, and second, a bumper rice crop was harvested at the end of 1943. The government later said it had spent Rs74,274,128 on direct relief between October 1942 and March 1944. This translates to just over USD20 million in 2019 and is thus a relatively minor amount of money (Brennan, 1988).

The victims had protested, however. They were the quasi-revolutionary protests of those distant from the state. Indeed, their protests had started even before the cyclone. The Indian National Congress had launched the "Quit India" movement in August 1942, part of a nation-wide nationalist protest against the boat denial policy. Mahatma Gandhi wrote vehement editorials. Support was strongest in the area most affected by the policy. This happened also to be the area worst hit by the cyclone. The government responded by arresting the Quit India leaders. After that, sporadic acts of sabotage against government property took place in the area even after it was inundated by the cyclone. Once the famine truly took hold, however, organised rioting disappeared. Radical protest from the margins of power failed to make its mark on either local or national governments whose priorities lay elsewhere. No national measures were taken to reduce the impact of any future cyclone disasters.

\section{Osaka Bay, 1934}

Osaka lies on two river deltas at the head of a north-east trending bay. This is the direction that most typhoons take in this region. Records of typhoons and their associated storm surges go back to the 7th century CE, with interruptions at times of political instability. Typhoons have killed many thousands of the city's inhabitants over the centuries. No fewer than 53 storm surge disasters have been recorded at Osaka over the last 1,200 years, of which 4 led to more than 100 deaths. Modern instrumental typhoon measurements began at Port Osaka in 1900, and Japanese meteorology had achieved independent theoretical heights by the 1920s (Miyagawa, 2014). Other typhoon-prone cities along the southeast coast of Honshu are Tokyo and Nagasaki. Tokyo had been hit by a typhoon with a $2.3 \mathrm{~m}$ surge in 1917, killing between 1,300 and 4,000. A 3 m storm surge in 1927 left 600 dead in towns near Nagasaki (Tsuchiya and Kawata, 1981, 1986).

Early in the morning of 21 September 1934, the strongest typhoon recorded at Osaka since modern measurements began struck the city and environs. Barometric pressure and wind 
DPM

30,1

speed measurements suggest it was a Category 2 or 3 storm on the Saffir-Simpson scale. It had weakened from a possible Category 5 after passing Cape Muroto. A storm surge of about $3 \mathrm{~m}$ on top of the falling astronomical high tide made the water rise to $4.2 \mathrm{~m}$. About a third of Osaka City, $49.3 \mathrm{~km}^{2}$, was inundated. The wind blew trains off their tracks. A lunatic asylum was swept away; 274 teachers and pupils died when their wooden school buildings collapsed in the wind. The death toll ran to a precisely enumerated 3,066.

In their historical study of Osaka storm surge disasters, Tsuchiya and Kawata (1986, p. 12) identify 1934 as an adaptation turning point. After it, "both soft and hard countermeasures against storm surges were greatly improved. In particular, a typhoon warning system was developed based on data collected by aircraft and meteorological radars. The construction of embankments in low-lying coastal areas was begun in 1934 and has been very effective in reducing the damage caused by storm surges." Why did this disaster have such a salutary effect on disaster governance in Japan, when nothing comparable happened in India and the Philippines at about the same time? The answer, once more, must be sought in an analysis of the distance between the victims and the state. Unlike those in the other two disaster zones, the victims here were close to the state on each of the four dimensions under consideration.

Culturally, Osaka is one of the oldest and most significant cities in Japan. It was twice briefly the imperial capital, in the 7th and 8th centuries CE. It has been known for centuries as the centre of Japanese culture, became an important port city since the 17th century and grew into Japan's major industrial centre since the late 19th century. The destruction of cultural treasures in the typhoon was reported immediately in the national newspapers and caused much distress. The floating pavilion of Lake Biwa that Hiroshige had painted, the ancient Shitennō-ji pagoda in Osaka and the famous park of Korakuen in Okayama, were among them. The death of many children while they were at school moved Japanese newspaper readers. A memorial service was held for them; a monument was planned. Reporting on the typhoon was abundant in the Japan Times - numerically almost twice as much as the corresponding 1942 disaster had yielded in the Times of India, even though the number of Japanese victims had been far less than in India [5]. Unlike the 1942 disaster in India, the 1934 disaster in Japan was perceived as a national crisis.

Geographically, too, the Kansai area struck by the typhoon was close to the centre of power, economic power especially. As Japan industrialised following the Meiji Restoration, Osaka became its premier industrial city. The city's population exploded in the first decades of the 20th century, reaching 4 million by 1934 [6]. It was famous worldwide as "the Manchester of the East" for its cotton spinning industries. Japan's exports were dominated by small and medium business, while the large zaibatsu catered to the domestic market. The 1934 typhoon destroyed 25,000 small factories producing cotton, wool, rayon and even munitions. The price of silk rose on the New York stock exchange on news that the typhoon had affected production (though this was also due to a Depression-era fall in the exchange rate). Warehoused fertiliser amounting to 45,000 tons was washed away.

The victims were close to the state along the class dimension too. This disaster had affected the country's powerful business sector. Infrastructure damage alone was estimated at $¥ 500$ million (USD 2.4bn in 2019 dollars), with commercial stock losses at $¥ 100$ million and damaged factories at $¥ 200$ million. When those who had suffered these losses demanded compensation and a lift on import bans to bring in 100,000 tons of extra steel for reconstruction (as well as to make up for an existing shortfall), they were heard. Institutionally, they enjoyed a lot of leverage.

The typhoon politics played out in the Diet (parliament) and the press. State subsidies were considered essential both to help compensate losses and invest in new infrastructure to prevent a recurrence. But the government had only $¥ 4 \mathrm{mn}$ in its emergency reserve (USD1mn, or USD19mn in 2019 dollars). Cabinet planned to take $¥ 10 \mathrm{mn}$ from the previous year’s surplus and make up the rest of the planned $¥ 200$ mn relief package by issuing government 
bonds - essentially printing money. Only an extraordinary session of the Diet could approve such a bold move. The lesson of the 1923 Tokyo Earthquake had not been forgotten: a big disaster demands national cooperation (JT 25/09/1934).

The Diet session was a problem to the government. Japan was in transition from a period of liberalisation to one of militarisation (Large, 2007). The assassination of the last civilian prime minister in 1932 by young navy officers marked the end of Japan's most robust period of democracy before the post-war American occupation. All subsequent prime ministers were non-party military officers. Militarists increasingly set the tone of public opinion and shaped policy beyond the reach of the Diet.

Yet the Diet continued to meet and retained certain competencies. Of the two main parties there, one, Minseitō, was reform-minded and seen as representing the rising middle class. It worked with organised labour and enjoyed considerable support in Osaka. It had led a number of cabinets in the preceding years. In the 1932 elections, amid growing Depressionera ultra-nationalism, it had lost to the conservative Seiyūkai. Yet, while both parties were financed by large zaibatsu, and both deferred to the military, both also promoted popular participation in politics and open foreign relations. Both saw the typhoon crisis as an opportunity to impress people's demands on an increasingly militarised government. Minseito threatened a no-confidence vote in the Diet if the government did not substantially increase its aid package. It also demanded an extended special Diet session to air its demands openly. Months of back-room negotiation followed. When the Diet did convene in December, the aid package had been doubled to over $¥ 400 \mathrm{mn}$. An extended Diet session allowed Minseito to explain to the public why the middle class needed more assistance. The relief package was heavy on engineering and assistance to industry. Serious measures were undertaken to prevent a recurrence. Typhoons were to be tracked by aircraft. The city was rezoned to relocate industries to safer areas. While the subsequent coastal dikes were to be destroyed again during the Second World War, the idea had taken root in state thinking that typhoon disasters were preventable. State institutions demonstrated a capacity to act decisively while maintaining a relatively consultative atmosphere.

Not everyone was as well-connected as the urban Minseitō constituency. The typhoon had carved a destructive path across Honshu and agricultural areas had been hit as well. Farmers there afterwards complained that they had been neglected. Their distance to the state had been too great. The rice crop - affected by both the typhoon and a preceding drought - was expected to be the worst in 30 years. But instead of supporting them by instituting a rice price floor, the government protected urban consumers with a rice price ceiling.

\section{Conclusion}

The victims of the three typhoon disasters considered here differed greatly in the distance that separated them from the state. Those in the Philippines and India were agrarian and poor. They lived far from the capital, were culturally uninteresting to mainstream discourse in the press, were seen by those in power as economically unproductive as a class and were too remote from the state's institutions to be able to influence them directly. If they engaged in "typhoon disaster politics" at all after the disaster - I know only of the radical Quit India movement in India - these were too ineffective to change elite perceptions. In both cases those perceptions were dominated by security concerns. Securitisation represents a failure of disaster citizenship.

Security concerns grew dominant because both countries were colonial and semiauthoritarian. Under such conditions, the great majority of the population is far removed from the state, while a small elite enjoys proximity to it. This left these states with low capacities to cope with multiple crises. Relief was allocated in the millions of US dollars on today's rates, but (beyond better forecasting) there was no structural adaptation after the typhoon to prevent a recurrence. 
DPM

30,1

The victims in Japan, by contrast, were industrial capitalists as well as small and medium businesspeople with their workers and families. They were close to the state along each of the four dimensions Davis specified. Their typhoon politics were contained within the formal consultative institutions over which they had influence (threatened as these institutions were by rising militarism). And they were effective. Japan was an independent country with a strong sense of national solidarity. Its politics remained moreover somewhat consultative. Under these conditions, many more people enjoyed short distances to the state than in the other two cases. Japan was a state with high capacities. The typhoon was seen as a national crisis. Relief was allocated in the billions of today's US dollars. Structural adaptations were made to mitigate future disasters.

This leads to two obvious but often neglected conclusions about the power dynamics surrounding historical typhoon disasters. The first is that the impact of a disaster on state politics is strong if the disaster strikes an urban industrial population close to the heart of power. Conversely, impact is weak if the disaster strikes an agrarian population in a peripheral rural area. The second is that protection from recurring typhoons is more likely if the state has high capacity (is wealthy) and if it practises democratic consultation. Protection is less likely if the state has low capacity (is poor) and if it is authoritarian. The latter situation is rife with collective action problems and results in state incoherence. My preliminary work on other 20th century typhoon disasters in these countries confirms this. Japan began massively to invest in typhoon disaster mitigation measures in 1959, after a powerful typhoon struck the third largest metropolitan area of a country that had become rich and democratic. India's impoverished east coast suffered numerous deadly storms, but the country finally implemented an effective evacuation regime after 1999, after national GDP had shot up. The economically and democratically challenged Philippines may still not have reached a typhoon disaster turning point even now. These conclusions resemble those of some earlier work on societal disaster learning. Albala-Bertrand (1993), for example, concluded that state disaster responses reflect dominant political philosophies and state capacities.

Moreover, the present paper offers a new, more inclusive framework to extend such work. A "distance" framework embraces both citizens and the state. When another study concluded that big disasters promote unrest which authoritarian states tend to suppress (Drury and Olson, 1998), the "distance" framework suggests that the social location of those causing unrest matters. When yet another concludes that US public policy change driven by "focusing events" such as hurricanes appears to be only incremental because federal lobbies are dependent on relief budgets (Birkland, 2006), the framework suggests research questions that extend to the informal social movement from below. A "distance" framework can illuminate disaster politics in the many typhoon-prone states - most in Asia-that are neither wholly democratic nor wholly authoritarian, neither wholly capacitated nor completely incoherent.

\section{Notes}

1. http://www.emdat.be/database (last accessed 28 January 2020).

2. A forthcoming book by James F. Warren will deal with the 1928 Philippines event at length.

3. The conversion from historical minimum barometric pressure readings to maximum sustained surface winds and hence to the widely used Saffir-Simpson scale is done with a formula developed by Brown et al. (2006).

4. This is why economists recommend instead dealing with a food crisis by letting the market balance supply and demand, while compensating those losers who suffer as a result of price fluctuations (Pinstrup-Andersen, ed, 2015).

5. For a year after each disaster, I counted the word "typhoon" (as used in Japan) and "cyclone" (India) respectively in the two papers. I normalised each by dividing by counts over the same period of a very common word in the English language ("would") and scaled up by multiplying by 1,000. The 
respective results were 21.3 (Japan for September 1934) and 12.5 (India for October 1942). A similar pattern can be observed for the two newspapers' reporting on other typhoon disasters in both countries.

6. https://www.statista.com/statistics/608273/japan-population-osaka/ (last consulted 28 January 2020).
Typhoon disaster politics in pre1945 Asia

\section{References}

Abinales, P.N. and Amoroso, D.J. (2005), State and Society in the Philippines, Rowman \& Littlefield Publishers, Lanham.

Albala-Bertrand, J.M. (1993), Political Economy of Large Natural Disasters: With Special Reference to Developing Countries, Clarendon Press, Oxford.

Anduaga, A. (2019), "History of typhoon science", in Hans Von Storch (ed.), Oxford Research Encyclopedias: Climate Science, Oxford University Press, Oxford, available at: https:// climatescience.oxfordre.com (accessed 10 May 2020).

Bankoff, G. (2003), Cultures of Disaster: Society and Natural Hazard in the Philippines, RoutledgeCurzon, London.

Bankoff, G. (2007), "Dangers to going it alone: social capital and the origins of community resilience in the Philippines", Continuity and Change, Vol. 22 No. 2, pp. 327-355.

Birkland, T.A. (2006), Lessons of Disaster: Policy Change after Catastrophic Events, Georgetown University Press, Washington, DC.

Brennan, L. (1988), “Government famine relief in Bengal, 1943”, Journal of Asian Studies, Vol. 47 No. 3, pp. 541-566.

Brown, D.P., Franklin, J.L. and Landsea, C.W. (2006), "A fresh look at tropical cyclone pressure-wind relationships using recent reconnaissance-based 'best track' data (1998-2005)", 27th Conference on Hurricanes and Tropical Meteorology, American Meteorological Society, Monterey, CA, April.

Burton, I., Kates, R.W. and White, G.F. (1993), The Environment as Hazard, 2 edn., Guilford Press, New York.

Carey, M. (2012), "Advanced review: climate and history: a critical review of historical climatology and climate change historiography”, WIREs Climate Change, Vol. 3 No. 3, pp. 233-249.

Church, C.M. (2017), Paradise Destroyed: Catastrophe and Citizenship in the French Caribbean, University of Nebraska Press, Lincoln.

Coppedge, M., Gerring, J., Knutsen, C.H., Lindberg, S.I., Skaaning, S.-E., Teorell, J., Altman, D., Bernhard, M., Steven Fish, M., Cornell, A., Dahlum, S., Gjerløw, H., Glynn, A., Hicken, A., Krusell, J., Lührmann, A., Marquardt, K.L., McMann, K., Mechkova, V., Medzihorsky, J., Olin, M., Paxton, P., Pemstein, D., Pernes, J., von Römer, J., Seim, B., Sigman, R., Staton, J., Stepanova, N., Sundström, A., Tzelgov, E., Wang, Y.-T., Wig, T., Wilson, S. and Ziblatt, D. (2018), "V-dem [Country-Year/Country-Date] dataset v8", varieties of democracy (V-dem) project”, available at: https://www.v-dem.net/en/ (accessed 28 January 2020).

Davis, D.E. (1999), “The power of distance: re-theorizing social movements in Latin America”, Theory and Society, Vol. 28 No. 4, pp. 585-638.

Drury, A.C. and Olson, R.S. (1998), "Disasters and political unrest: an empirical investigation”, Journal of Contingencies and Crisis Management, Vol. 6, pp. 153-61.

Governor General of the Philippine Islands (1930), Annual Report, 1928, United States Government Printing Office, Washington, DC.

Greenough, P.R. (1982), Prosperity and Misery in Modern Bengal: The Famine of 1943-1944, Oxford University Press, Oxford.

India Meteorological Department (IMD) (2018), "Cyclone eAtlas - IMD - tracks of cyclones and depressions over North Indian Ocean, 1891 - 2018”, available at: http://www.rmcchennaieatlas. tn.nic.in/ (accessed 28 January 2020). 
DPM

30,1

IPCC (2007), "Climate Change 2007: impacts, adaptation and vulnerability: Working Group II contribution to the intergovernmental panel on climate change - fourth assessment report: summary for policymakers", Intergovernmental Panel on Climate Change (IPCC), Brussels.

Johnson, S. (2011), Climate and Catastrophe in Cuba and the Atlantic World in the Age of Revolution, University of North Carolina Press, Chapel Hill.

Kingsbury, B. (2019), An Imperial Disaster: The Bengal Cyclone of 1876, Oxford University Press, New York.

Knutson, T., Camargo, S.J., Chan, J.C.L., Emanuel, K., Ho, C.-H., Kossin, J., Mohapatra, M., Satoh, M., Sugi, M., Walsh, K. and Wu, L. (2020), "Tropical cyclones and climate change assessment, part II: projected response to anthropogenic warming", Bulletin of the American Meteorological Society, Vol. 101 No. 3, pp. E303-E322.

Large, S.S. (2007), "Oligarchy, democracy, and fascism", in Tsutsui, W.M. (Ed.), A Companion to Japanese History, Blackwell, Malden, MA, pp. 156-171.

Lin, T.-H. (2015), "Governing natural disasters: state capacity, democracy, and human vulnerability", Social Forces, Vol. 93 No. 3, pp. 1267-1300.

Miyagawa, T. (2014), "Establishing 'East Asian meteorology' in the expanding empire: typhoon study in the early twentieth century Japan", AAS-in-Asia conference presentation, Singapore, 18 July.

Needham, H.F., Keim, B.D. and Sathiaraj, D. (2015), "A review of tropical cyclone-generated storm surges: global data sources, observations, and impacts", Reviews of Geophysics, Vol. 53, pp. $545-591$.

Pelling, M. and Dill, K. (2010), "Disaster politics: tipping points for change in the adaptation of sociopolitical regimes", Progress in Human Geography, Vol. 34, pp. 21-37.

Perez, L.A. (2001), Winds of Change: Hurricanes and the Transformation of Nineteenth-Century Cuba, The University of North Carolina Press, Chapel Hill; ProQuest 2001, Ann Arbor, Michigan.

Pinstrup-Andersen, P. (Ed.) (2015), Food Price Policy in an Era of Market Instability: A Political Economy Analysis, Oxford University Press, Oxford.

Ribera, P., García-Herrera, R., Gimeno, L. and Hernández, E. (2005), "Typhoons in the Philippine islands, 1901-1934", Climate Research, Vol. 29, pp. 85-90.

Rohland, E. (2019), Changes in the Air: Hurricanes in New Orleans from 1718 to the Present, Berghahn Books, New York.

Tsuchiya, Y. and Kawata, Y. (1981), "Risk to life, warning systems, and protective construction against past storm surges in Osaka Bay", Journal of Natural Disaster Science, Vol. 2 No. 3, pp. 35-55.

Tsuchiya, Y. and Kawata, Y. (1986), "Historical study of changes in storm surge disasters in the Osaka area”, National Disaster Science Japan Society for Natural Disaster Science, Vol. 8 No. 2, pp. 1-18.

Vogel, B. (2009), "Bibliography of recent literature in the history of meteorology: twenty six years, 1983-2008", History of Meteorology, Vol. 5, pp. 23-125.

Warren, J.F. (2018), "Typhoons and droughts: food shortages and famine in the Philippines since the seventeenth century", International Review of Environmental History, Vol. 4 No. 2, pp. 27-44.

\section{Corresponding author}

Gerry van Klinken can be contacted at: g.a.vanklinken@uva.nl

For instructions on how to order reprints of this article, please visit our website:

www.emeraldgrouppublishing.com/licensing/reprints.htm

Or contact us for further details: permissions@emeraldinsight.com 